AL IBTIDA: JURNAL PENDIDIKAN GURU MI (2021) Vol 8 (2) : 161-177

DOI: http://dx.doi.org/10.24235/al.ibtida.snj.v8i2.9175

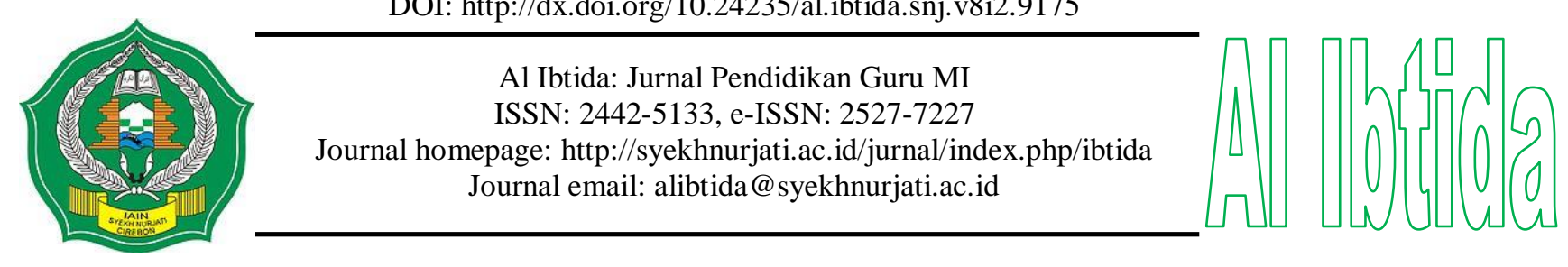

\title{
Enhancing Students' Science Literacy Skills; Implications for Scientific Approach in Elementary School
}

\author{
Kartimi* \\ *Department of Natural Science Education, Faculty of Tarbiyah and Teacher Training, \\ Institut Agama Islam Negeri Syekh Nurjati Cirebon, Indonesia. \\ Email: kartimi.iain@gmail.com \\ Widodo Winarso ${ }^{* *}$ \\ **Department of Mathematics Education, Faculty of Tarbiyah and Teacher Training, \\ Institut Agama Islam Negeri Syekh Nurjati Cirebon, Indonesia. \\ Email: widodo.iain@gmail.com
}

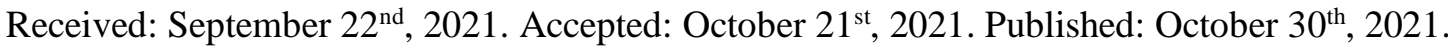

\begin{abstract}
Science literacy skills of elementary school students in the era of 21 st-century learning are indispensable, scientific literacy skills can be improved through the application of a scientific approach. This study aims to analyze the scientific literacy ability of elementary school students through the application of a scientific approach. The experimental method with a pretest-posttest group design was used in this study. Simple Random Sampling, consisting of an experimental class and a control class, was applied to elementary schools in Cirebon, Indonesia. The scientific literacy skills test (TOSLS) measures students' literacy skills, while the observational assessment measures students' responses to the scientific approach. The data analysis technique used independent sample T-Test and Mann-Whitney U. The results showed that students' learning activities in the application of scientific learning experienced an increase in scientific literacy skills with very strong criteria. Student learning activities in the experimental class have a higher percentage over the control class. The research hypothesis shows that there is a difference in the improvement of students' scientific literacy skills between the experimental class and the control class of elementary school students. Thus, the application of a scientific approach contributes to students' scientific literacy skills.
\end{abstract}

Keywords: scientific literacy, scientific approach, science education.

\begin{abstract}
Abstrak
Keterampilan literasi sains siswa sekolah dasar di era pembelajaran abad 21 sangat diperlukan. Keterampilan literasi sains dapat ditingkatkan melalui penerapan pendekatan saintifik. Penelitian ini bertujuan untuk menganalisis kemampuan literasi sains siswa sekolah dasar melalui penerapan pendekatan saintifik. Metode eksperimen dengan desain pretest-posttest group design digunakan dalam penelitian ini. Simple Random Sampling, terdiri dari kelas eksperimen dan kelas kontrol di sebuah sekolah dasar di Indonesia. Tes keterampilan literasi sains (TOSLS) mengukur kemampuan literasi siswa, sedangkan penilaian observasional mengukur respons siswa terhadap pendekatan saintifik. Teknik analisis data menggunakan
\end{abstract}


independent sample T-Test dan Mann-Whitney U. Hasil penelitian menunjukkan bahwa aktivitas belajar siswa ketika diterapkan pendekatan saintifik mengalami peningkatan keterampilan literasi sains dengan kriteria sangat kuat. Aktivitas belajar siswa pada kelas eksperimen memiliki persentase yang lebih tinggi dibandingkan dengan kelas kontrol. Hipotesis penelitian menunjukkan bahwa terdapat perbedaan peningkatan kemampuan literasi sains siswa antara kelas eksperimen dan kelas kontrol siswa SD. Dengan demikian, penerapan pendekatan saintifik berkontribusi terhadap kemampuan literasi sains siswa.

Kata kunci: literasi ilmiah, pendekatan ilmiah, pendidikan sains.

\section{INTRODUCTION}

Science in elementary school is one of the subjects that occupy an essential role in education. This is because science can be a provision for students in facing various challenges in the global era. Therefore, a learning method is needed to prepare students to have good competencies and be literate in science and technology, think logically, critically, creatively, argue correctly, and communicate and collaborate (Vieira \& Tenreiro-Vieira, 2016). Science literacy can be termed scientific literacy ability, namely the ability to understand science, communicate science (oral and written), and apply scientific skills to problem-solving problems so that they have a high attitude and sensitivity to themselves and their environment in making decisions based on scientific considerations (Cajas, 2001).

Science literacy skills are skills that students have from learning outcomes in class. These skills include scientific skills, identifying questions, and drawing conclusions based on evidence to understand and make decisions regarding nature and its changes due to human activities (Lawless et al., 2018; Murcia, 2009). Students cannot be classified as "scientifically literate" or "scientifically illiterate", instead, they are classified in terms of developing scientific literacy from less developed to more developed (Laugksch, 2000). Students with less developed literacy skills can solve problems in simple situations, while those with more developed literacy skills can solve problems in complex situations. Holbrook \& Rannikmae (2009) added an attitude component in scientific literacy: independence in learning science, the ability to think scientifically, curiosity, and the ability to think critically. Competencybased scientific literacy model, which is the result of scientific literacy is not only qualified in content and processes and scientific skills but also has attitudes and ethics.

Learning with a scientific approach invites students to observe various phenomena that often occur in students' daily lives (Wieman, 2007). Through this observing activity, students are expected to find problems related to the knowledge concepts. According to Harmsen (2007), direct observation of a phenomenon or its simulation provides meaning for students. The object displayed is a stimulus for students to learn. The right stimulus is needed in 
learning in elementary school. According to Firman, Baedhowi, \& Murtini (2018), the process of observing can occur in natural objects or simulations that can be used as a stimulus to stimulate students to ask questions at the beginning of the learning stage. Teachers provide opportunities to ask students to develop curiosity, so students are motivated to learn the material they are studying. The low level of students' questions was correlated with learning achievement (Cuccio, Schirripa \& Steiner, 2000; Wilen \& Clegg Jr, 1986).

The stage of collecting information in a scientific approach is an activity that seeks to answer the questions. One of the student activities to gather information is to design and conduct experiments. Demonstration activities can make learning situations like the real world for students. This stage provides students with opportunities to practice problemsolving skills, provide opportunities for hands-on experiences, think and reflect on students' knowledge actively (Grace, 2001).

The associating stage of the scientific approach provides opportunities for students to connect between previous concepts, the concepts being studied, and their relationship to other materials so that they are expected to improve students' scientific literacy (Damayanti, Suyatna, Warsono \& Rosidin, 2017). Communicating activities in a scientific approach provide opportunities for students to convey and account for their findings. So, it can be concluded that all learning activities in a scientific approach can improve students' scientific literacy.

The PISA survey results from 2000 to 2018 placed Indonesia as one of the countries with a low scientific literacy rating (Narut \& Supardi, 2019). PISA results for Indonesian students in 2015 alone are still below the OECD country's average science score. The average value of science for scientific literacy in OECD countries is 493, while Indonesia has only achieved a score of 403. This shows a gap in treating science education at the elementary education level (Asyhari, 2015). In the national education system, scientific literacy has begun to be accommodated in the 2006 Curriculum or the Education Unit Level Curriculum (KTSP) and is more clearly visible in the 2013 Curriculum. Implementing the 2013 curriculum in learning at the elementary school level through a scientific approach strongly emphasizes learner-centered learning (Selasih, 2019; Taji, 2005). However, the fact is that this has not been applied to learning activities in elementary schools in most places in Indonesia (Gunawan, 2017). There are important issues in science education policy at the elementary school level (Sari, 2012). Indonesian education must develop a culture of scientific literacy as a prerequisite for 21 st-century life skills through integrated elementary education through thematic learning (Rahayu, 2017). 
In line with these problems, there are several studies related to students' scientific literacy skills. Aulia, Poedjiastoeti, \& Agustini (2018) conducted a survey related to the effectiveness of guided inquiry-based teaching materials in improving scientific literacy skills. There is a positive effect between the development of guided inquiry-based learning materials and the improvement of various aspects of scientific literacy skills for students. Teachers must prepare multiple literature sources, master the steps of learning, and manage the class well. Karademir \& Ulucinar (2017) stated a causal relationship between students' critical reading skills, scientific literacy skills, and students' attitudes towards scientific literacy in students. In building students' scientific concept skills, they consist of aspects of scientific literacy, which include aspects of scientific knowledge, scientific competence, scientific context, and factors that affect scientific literacy skills themselves (Fakhriyah, Masfuah, Roysa, Rusilowati, \& Rahayu, 2017; Gormally, Brickman, \& Lutz, 2012). Moreover, increasing scientific literacy can also be done using Edmodo-based educational materials (Putri, Ulhusna, Zakirman \& Gusta, 2020). However, all the results of these studies have not focused on the learning problems of elementary school students. The study still provides explanations related to teaching materials and the factors that influence them. Studies that discuss scientific approaches to learning activities in elementary schools have not been widely carried out. So it is necessary to research to test the scientific literacy skills of elementary school students.

Referring to the research problem, there are three objectives in this research, among others: 1) to find out the results of the application of the scientific approach in elementary schools; 2) Analyze the difference in increasing scientific literacy between classes that apply a scientific approach and classes that do not apply a scientific approach; and 3) to find out student responses to the application of a scientific approach to learning activities in elementary schools.

Science literacy skills have begun to be accommodated in the curriculum. In this curriculum, the competency standards of graduates are translated into core competencies. The core competencies (KI) in question are divided into 3 aspects, namely KI 1 and $\mathrm{K} 2$ are aspects of attitude, KI 3 concerning knowledge, and KI 4 about skills (Yusnita, Apriliani, Abbas \& Rochgiyanti, 2021). The approach used in this curriculum is the scientific approach (Gunawan, 2017). The scientific approach emphasizes learner-centered learning through the stages of the scientific approach. Learning with a scientific approach consists of five main learning experiences: observing, asking questions, gathering information/experiments, associating/processing information, and communicating (Alberida, 2020). Implementing a scientific approach improves students' scientific literacy (Afriana, Permanasari \& Fitriani, 
2016). Scientific learning can enhance the profile of students' scientific literacy skills (Dragoş $\&$ Mih, 2015). The scientific approach invites students to observe various phenomena that are familiar with the daily lives of students. Through this observing activity, students are expected to find problems related to the concept of knowledge that they will learn. Thus, researchers are interested in studying the science literacy skills of elementary school students through the application of a scientific approach.

\section{METHODS}

Quantitative research using experimental methods was applied in elementary school students in Cirebon, Indonesia. The quasi-experimental design was chosen in this study because it had a control group. However, it did not fully function to control for external variables that affect the execution of the experiment (Miller, Smith \& Pugatch, 2020). The technique used in this study is pretest-posttest control group design (Bonate, 2000). Two classes were selected directly, and then given a pretest to determine the initial state. Is there a difference between the experimental class and the control class? Then, the experimental class was treated using a scientific approach, while the control class continued to use the conventional method. After completing the treatment, both classes were given a posttest to determine changes in students' scientific literacy abilities.

The sampling technique in this study used simple random sampling (Gupta \& Shabbir, 2008). A total of 44 students consisting of the control class and the experimental class were used as subjects in this study. The experimental class consisted of 12 male students and 10 female students. In comparison, the control class consisted of 7 male students and 15 female students. All students are in grade 4 in elementary school.

Theoretical data were obtained from various books, journals, proceedings, other scientific works related to the research conducted. In comparison, the source of empirical data is received by conducting observations and experimental research with the instruments used, namely the Science Literacy Ability Test (TOSLS) and assessment observations. TOSLS is used to measure students' literacy skills (Gormally, Brickman \& Lutz, 2012; Waldo, 2014). A total of 40 multiple choice questions were given to the research subjects, with indicators adapted and developed from Gormally, Brickman, Hallar \& Armstrong (2009). Whereas the observation assessment is used to measure student responses to the application of the scientific approach. Student responses are calculated through the learning activities carried out. Student learning activities observed in this study include (1) asking; (2) answering questions; (3) data collection; (4) using scientific evidence; and (5) doing assignments according to the teacher's instructions (Abdullah, Bakar \& Mahbob, 2012). The results of 
these observations are then presented and interpreted based on student activities during learning using a scientific approach.

The TOSLS results obtained were statistically tested, namely the normality test and homogeneity test. The results of the normality test that have a significance value $>0.05$ are said to be normally distributed. If the homogeneity test has a significance value $>0.05$, it is said to be homogeneously distributed. Furthermore, hypothesis testing is carried out. This hypothesis test uses the Independent Sample T-Test parametric test and the Mann-Whitney U non-parametric test. The hypothesis test results are those with a significance value $<0.05$, meaning that they accept $\mathrm{H}_{1}$ and reject $\mathrm{H}_{0} \cdot \mathrm{H}_{1}$ of this research is there is a significant difference in the improvement of students' scientific literacy between classes that apply the Scientific approach and classes that do not apply the scientific approach. The N-Gain test is used to obtain a neutral $\mathrm{N}$-gain value to eliminate the assumption that the largest $\mathrm{N}$-gain value shows the best scientific literacy results.

\section{RESULTS AND DISCUSSION Application of Scientific Approach}

The results of the application of the scientific approach can be measured through the assessment of student learning activities. Two observers evaluate student learning activities; each observer is tasked with observing two groups with each group member consisting of 4 or 5 students. Observation of student learning activities refers to 5 indicators. According to Abdullah, Bakar \& Mahbob (2012), student learning activities consist of (1) asking questions, (2) answering questions, (3) collecting data, (4) using scientific evidence, and (5) doing the task according to the teacher's instructions. The differences in the results of the observer's observations on the five student learning activities are as follows. 
Kartimi, Widodo Winarso, Enhancing Students’ Science Literacy Skills...

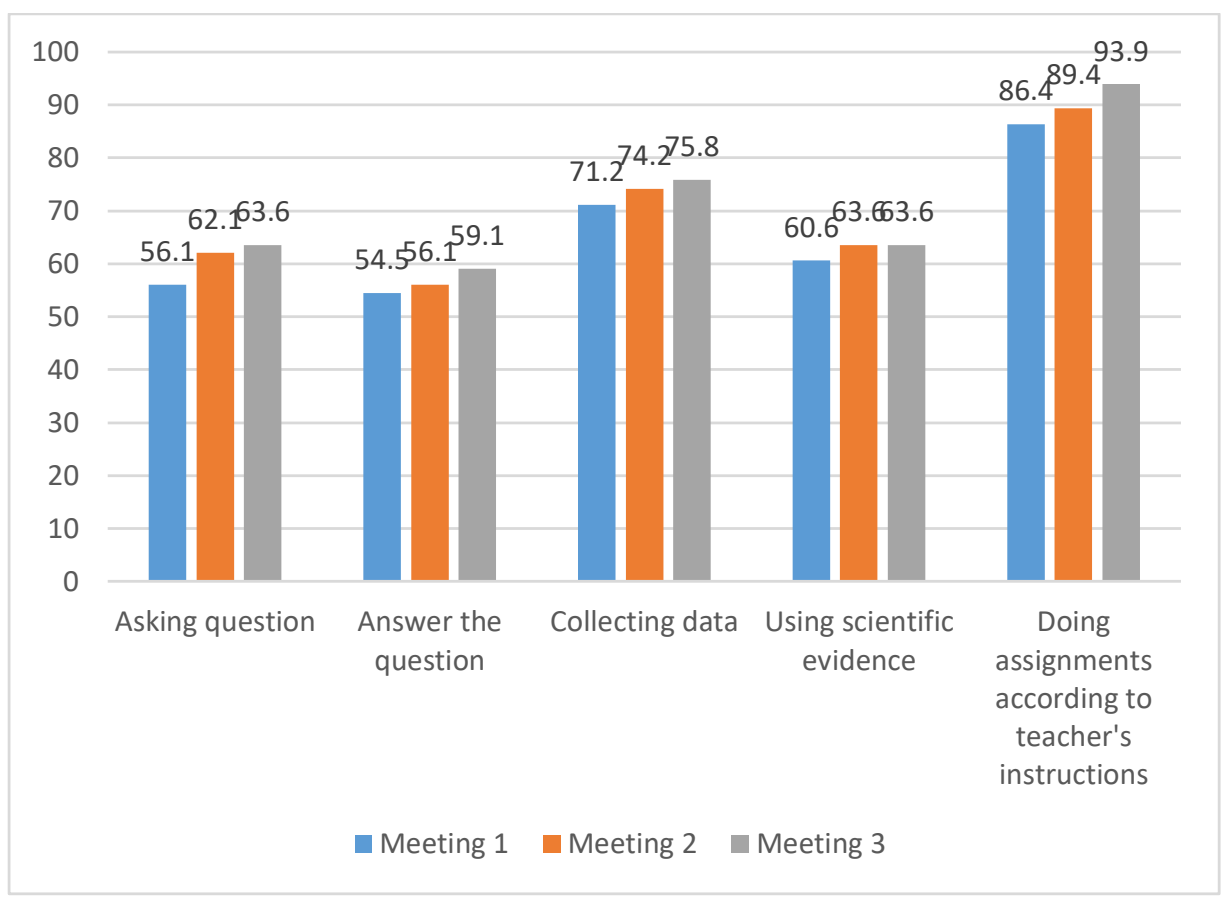

Figure 1. Experimental class student learning activities

Based on Figure 1, descriptively, there is an increase in each indicator in the three learning meetings conducted. Student learning activities with the highest average score are found to do assignments according to the teacher's instructions. The lowest average value is on the indicator of asking questions. Student learning activities in the indicators of collecting data at each meeting have increased. This happens because students are asked to focus on collecting data requested by the teacher. Data collection activities, according to worksheets during observations are made by students during learning activities. The increase in the average value of student learning activities in each meeting always increases. The lowest average value was obtained at the first meeting and raised high at the second meeting. At the first meeting, the experimental class students had never done or were treated with the scientific approach, so that students were still adapting to this approach. Students still feel tense at the first meeting, so the average score obtained is still low.

In the first indicator, students' learning activities in asking questions at each meeting have increased quite well. It can be said that the indicator of asking questions has a low value when compared to the indicator of collecting data. The low indicator is because students use the lecture method that the teacher has done every time they teach. This condition occurs because the students who are the research samples are new, so students are not familiar with the scientific approach used in learning activities. This is in line with the operant conditioning learning theory (Skinner, 1971; Akpan, 2020; Bąbel, 2020). The formation of behavior can be done by conditioning using an instrument (scientific approach). A scientific approach is used 
to provide consequences for the behavior produced by students in learning activities (Santrock, 2011).

The second activity is the indicator of answering questions. The indicator is that students can answer questions from their friends or from their teachers or propose solutions to questions given by their friends and teachers. The average value of the activity indicator in answering questions is almost the same as the activity indicator asking questions and is included in the lowest average value. The cause of the low activity of answering this question is because students are not accustomed to expressing their opinions in solving a problem by answering questions to overcome these problems (Hamza \& Griffith, 2006). The activity of answering questions increased from the beginning of the meeting to the third meeting. The increase in the average value of the activity indicator in answering questions was included in the low criteria at the first meeting and then increased at the second meeting to the third meeting, which is a sufficient criterion.

The learning activities on the indicators of collecting data. In the results of the analysis of data collection, there was an increase in each meeting. This data collection activity has very strong criteria. This happens because students feel happier learning by observing pictures through student worksheets compared to not observing pictures. Image visualization is given through student worksheets. According to Gordin, Polman \& Pea, (1994), the ease of observation in data collection can be built through the realization of concrete observations so that students are more interested and motivated in collecting data on these learning activities. This activity can be regarded as scientific work; Ellis (2014) said that scientific work habits are expected to foster habits of thinking and acting that reflect the mastery of knowledge, skills, and attitudes possessed by students.

Furthermore, the last activity observed was doing the task according to the teacher's instructions. Activities with indicators of doing tasks according to teacher instructions can be said as a form of student responsibility in the learning process. Each activity meeting with indicators of doing tasks according to the teacher's instructions has a percentage value for each meeting with a difference in the increased value that is not too far away. The score was $86.4 \%$ at the first meeting, the second meeting was $89.4 \%$, and the third meeting was $93.9 \%$. Meanwhile, the criteria are included in the very strong criteria. The high average score on the indicators of doing assignments according to the teacher's instructions, because students are used to being responsible for learning, one of which is by doing tasks according to the teacher's instructions. As for more detail, the value of the student worksheets of each group in the learning activities are as follows. 
Table 1 . The value of learning activities by group

\begin{tabular}{lllll}
\hline Meeting & Group-1 & Group-2 & Group-3 & Group-4 \\
\hline 1 & 85 & 82,5 & 72,5 & 75 \\
2 & 88 & 88 & 90 & 72 \\
3 & 89 & 81 & 73 & 73 \\
\hline Sum & 262 & 251,5 & 235,5 & 220 \\
\hline Average & 87,3 & 83,3 & 78,5 & 73,3 \\
\hline
\end{tabular}

Based on table 1, group one is the group that has the highest average score. The activity of collecting data makes students accustomed to filling out student worksheets from observations made. In addition, it can be seen that the scores in groups 3 and 4, the third meeting were smaller than the previous meeting. This is due to the lack of cohesiveness of students in the group, resulting in filling out student worksheets that are less precise and complete when compared to groups 1 and 2. The indicators use scientific evidence. Students are asked to present the results of their group work. Students make observations through the pictures provided on the worksheet. This activity is an activity from the attitude aspect of scientific literacy (Laugksch, 2000). The average score obtained at the first meeting, second meeting until the third meeting was $66 \%$ for the first meeting, $69 \%$ for the second meeting, and $71 \%$ for the third meeting. If interpreted, the average value of activity with indicators using scientific evidence is included in the sufficient criteria. The low value of the indicator using scientific evidence because time limits the percentage of observations. So that only a few students do this activity. Even though this activity can be one of the group communications tools to exchange ideas about the observations obtained by each group.

\section{Differences of Enhancing in Students' Science Literacy Skills}

The scientific approach can provide direct and meaningful experiences for students. Students can develop their competencies to be more scientific to learn about scientific knowledge and do it sequentially in learning activities (Drummond \& Fischhoff, 2017). These skills can be interpreted as students' science literacy skills (Hernawati, Amin, Al Muhdhar, \& Indriwati, 2019). 


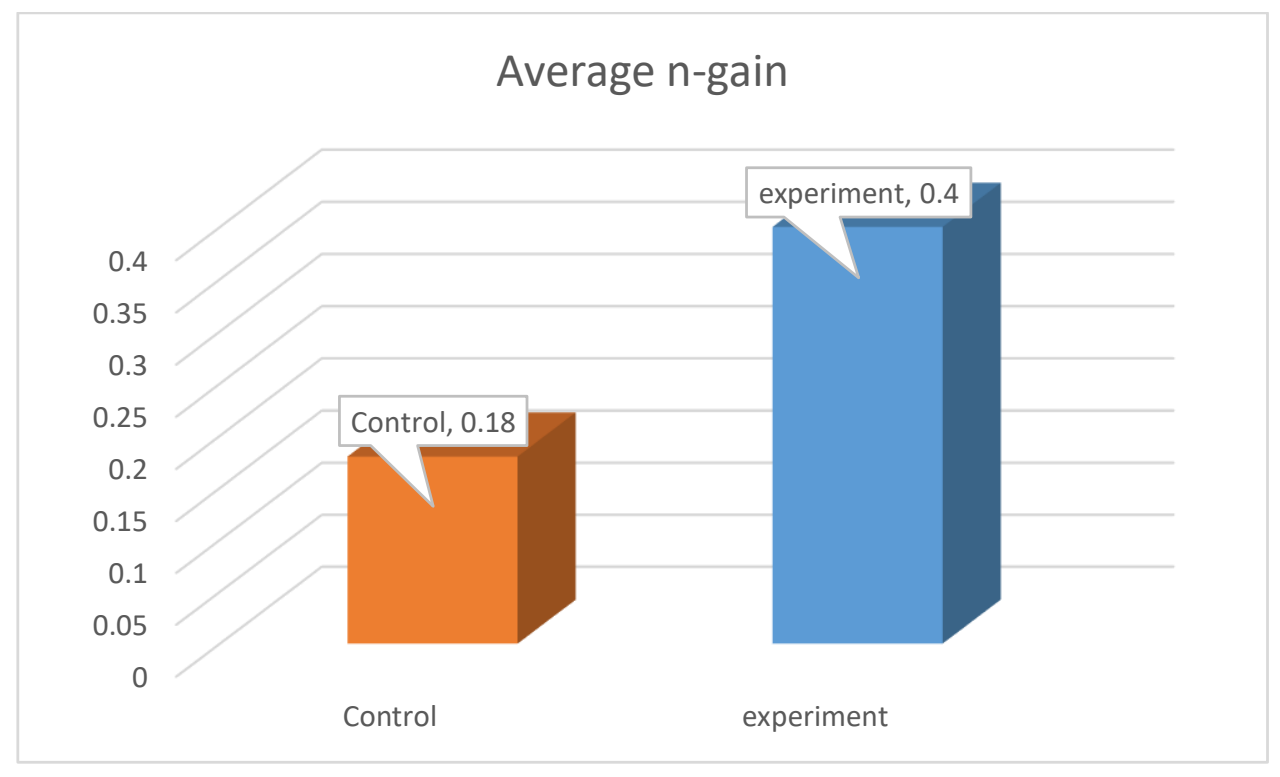

Figure 2. Differences in students' scientific literacy (pretest)

Based on Figure 2, the pretest results show that the scientific literacy ability is still less than a score of 60 (minimum mastery of learning). This is because the learning process has not paid attention to students' scientific literacy. In addition, there is also no significant difference between the two control and experimental classes. Giving treatment that can improve students' scientific literacy also needs to be done. Preliminary analysis is required to find out the initial reference for students' science literacy skills. According to Vignoli (2018), the initial ability is very important in increasing the meaningfulness of learning, which has an impact on facilitating the internal processes within the students themselves when studying next.

Furthermore, the treatment of the application of learning with a scientific approach is carried out. The research data was obtained from the pretest and post-test results tested on students; N-Gain then analyzed science literacy skills with the following results. Before testing the hypothesis, the research data were tested for normality and homogeneity. The test results show that the data from the research on science literacy skills are categorized as normal and homogeneous. Thus, the research data continued to be tested for hypotheses. Hypothesis testing using Independent sample T-test. The results of hypothesis testing are as follows.

Table 2. Results of hypothesis test based on N-gain

\begin{tabular}{llll}
\hline Data & Hypothesis testing & Significance & Conclusion \\
\hline N-Gain & Independen sample T tes & 0,000 & $\mathrm{H}_{0}$ rejected \\
\hline
\end{tabular}


Table 2 shows that overall there are significant differences between the control and experimental classes on students' science literacy skills. The science literacy skills tested include three aspects consist of context, knowledge, and competence. Descriptively, the data on the results of science literacy skills are as follows.

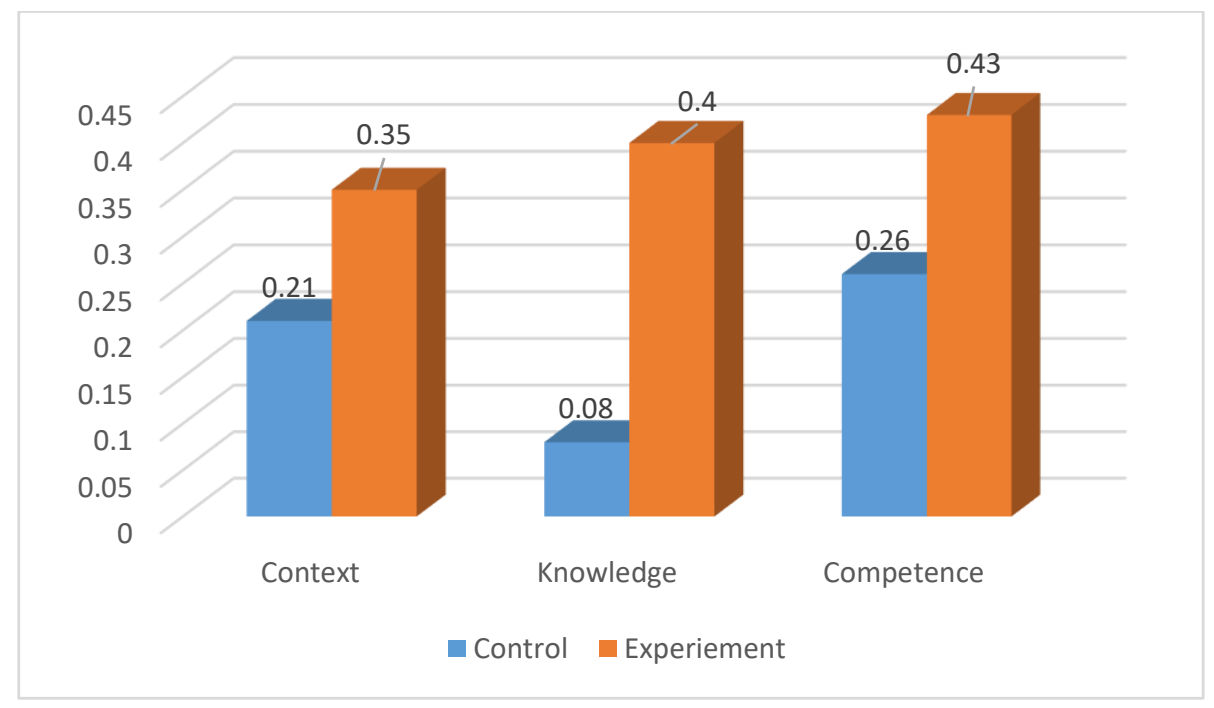

Figure 3. Average N-Gain in the aspect of science literacy skills

The average value in the context aspect, the control class, is lower than the experimental class. The difference between the two is quite far, which is 16.76 . The control class in the context aspect is 42,045 , while the experimental class is 58.81 . This much different difference shows that the initial ability of students in the control class is much lower than the experimental class.

The average value of competence of the control class is lower than the experimental class with a difference between the two groups accounting for 14,547 . The difference is not so big that the initial abilities of students in the control class and the experimental class are not too different. The low aspect of competence with other aspects is because students still experience confusion in analyzing the explanation of a problem that students know about.

Based on the three indicators of science literacy, skills in the experimental class show an increase. The knowledge aspect has the highest value compared to the experimental and control classes' other two aspects. In the aspect of competence, it gets the second-highest score after the knowledge aspect. This shows that students understand the concept of material both in the control class through a conventional approach and in the experimental class through a scientific approach. The context aspect shows the smallest value in both the control and experimental classes. This is in line with Abdulhak's opinion (2017) that knowledge needs to be given at the beginning of learning activities. Meanwhile, the context aspect experienced a slight increase in the control class. This happens because students have 
difficulty understanding the concepts of the material being taught. The knowledge aspect is the improvement obtained by the experimental class in succession from the highest to the lowest increase. The competence aspect is in second place, while the context aspect is in third. Further analysis of the hypothesis of the three aspects using the Mann-Whitney $U$ and Independent sample T-test. The results of the analysis are as follows.

Table 3. The N-Gain hypothesis test on the aspect of science literacy skills

\begin{tabular}{cccc}
\hline Aspect & Different Test & $\begin{array}{c}\text { Significance. } \\
(\mathbf{2} \text { tailed })\end{array}$ & Conclusion \\
\hline Context & Mann-Whitney $U$ & 0,027 & $\mathrm{H}_{0}$ rejected \\
Knowledge & Mann-Whitney $U$ & 0.006 & $\mathrm{H}_{0}$ rejected \\
Competence & T test & 0.050 & $\mathrm{H}_{0}$ rejected \\
\hline
\end{tabular}

Based on Table 3, the results of indicators that are not normally distributed are tested for hypotheses using the Mann-Withney U. In contrast, the normality of data distribution is tested for hypotheses using the independent sample T-test. The context aspect shows a significance value of 0.027 , then the knowledge aspect significance value is 0.006 , and the significance value for the competence aspect is 0.050 . So, the three aspects are, $\mathrm{H} 0$ or rejected. Thus, there are significant differences in improving students' scientific literacy in terms of context, knowledge, and competence. Based on the results of this study, the lower achievement of students' scientific literacy in the experimental class can be influenced by several factors, such as the level of difficulty of the pretest and posttest questions and the lack of thoroughness of students in answering the given questions. However, the results obtained are based on the significant $\mathrm{N}$-gain test scores in these three aspects, so it can be interpreted that the three aspects of scientific literacy have been successfully improved by applying the scientific approach to elementary school students in Cirebon, Indonesia. It is important to note that assessing scientific literacy over the school years alone does not determine students' final level of scientific literacy skills. The aim is only to measure the effectiveness of science learning in building attitudes, values, basic skills, knowledge, and understanding of science. Thus, assessing scientific literacy over the years in school only shows the beginning of the scientific literacy possessed by students. Therefore, the assessment of scientific literacy is not only in answering questions but also in the attitude of everyday students in solving a problem.

\section{Student Responses to the Application of the Scientific Approach}

Student responses to the application of the scientific approach were measured by a questionnaire. The Likert scale is arranged in the form of questions/statements distributed to 22 students in the experimental class. The results of the student response analysis showed that 
most of them fit into the very strong criteria. The results of the study are presented in the following figure.

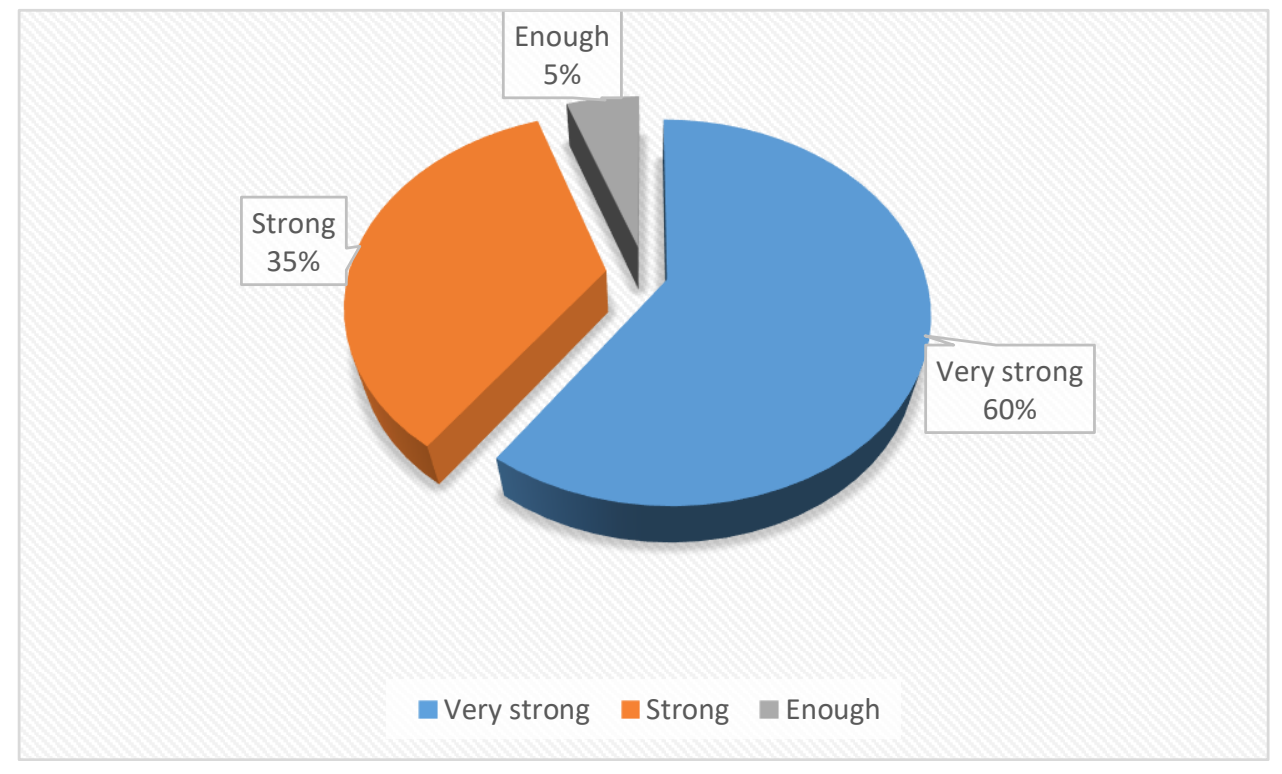

Figure 4. Student responses to the application of the scientific approach

Based on Figure 4, students' responses to the application of the scientific approach are very strong criteria getting a score of $60 \%$ of students, strong criteria of $32 \%$ of students, and sufficient criteria of $5 \%$ of students. The results indicate that the application of the scientific approach received a good response from the students. The students prefer learning with a scientific approach because it provides a new atmosphere in the learning process for students. Learning with a scientific approach requires students to be more active as well as make students more enthusiastic in the classroom learning activities. This can happen because the scientific approach is an approach that can make students more involved in learning activities (Bensley \& Murtagh, 2012). Students are given more opportunities to think independently, express opinions, and ask questions (Tsevreni, 2011); so the students do not feel bored during the learning process. Learning activities following a student-centered approach could create an educational climate that could arouse students' interest, passion, and enthusiasm (Krahenbuhl, 2016).

\section{CONCLUSION}

Students' learning activities in the application of the scientific approach in each meeting are constantly increasing. Collecting data and doing assignments according to the teacher's instructions are included in very strong criteria. In comparison, the criteria are sufficient in asking questions, answering questions, and using scientific evidence. This is a proof that the scientific approach can increase student activity in learning. There is a significant difference 
in the increase in scientific literacy between the classes that apply the scientific approach and the classes that do not use the scientific approach. In addition, students gave a very strong response of $55 \%$ to applying the scientific approach. This data prove that the application of the scientific approach gets a positive response from students. A scientific approach is a scientific-based approach, which includes observing, asking questions, gathering information, associating or reasoning, and communicating. So that learning can contribute to students providing direct experience and the application of the nature of science, which is not only limited to theoretical learning.

\section{REFERENCES}

Abdulhak, I. (2017). Implementation of scientific approach-based learning. Int. J. Educ. Res, 5(8), 221-230.

Abdullah, M. Y., Bakar, N. R. A., \& Mahbob, M. H. (2012). The dynamics of student participation in the classroom: observation on level and forms of participation. Procedia-Social and Behavioral Sciences, 59, 61-70. https://doi.org/10.1016/j.sbspro.2012.09.246

Afriana, J., Permanasari, A., \& Fitriani, A. (2016). Project-based learning integrated to stem to enhance elementary school students' scientific literacy. Jurnal Pendidikan IPA Indonesia, 5(2), 261-267. https://doi.org/10.1088/1742-6596/1491/1/012030

Akpan, B. (2020). Classical and Operant Conditioning-Ivan Pavlov; Burrhus Skinner. In Science Education in Theory and Practice (pp. 71-84). Springer, Cham. https://doi.org/10.1007/978-3-030-43620-9_6

Alberida, H. (2020). The Implementation of Scientific Approach in Learning Science Through Problem Solving. In International Conference on Biology, Sciences, and Education (ICoBioSE 2019) (pp. 349-353). Atlantis Press. https://doi.org/10.2991/absr.k.200807.071

Aprillianti, L. (2018). Comparison between Concept of Evaluation on KTSP Curriculum and 2013 Curriculum. In UICELL Conference Proceeding (No. 2, pp. 95-109). https://doi.org/10.26811/peuradeun.v9i2.510

Asyhari, A. (2015). Profil peningkatan kemampuan literasi sains siswa melalui pembelajaran saintifik. Jurnal Ilmiah Pendidikan Fisika Al-Biruni, 4(2), 179-191. https://doi.org/10.24042/jpifalbiruni.v4i2.91

Aulia, E. V., Poedjiastoeti, S., \& Agustini, R. (2018). The effectiveness of guided inquirybased learning material on students' science literacy skills. In Journal of Physics: Conference Series (Vol. 947, No. 1, p. 012049). IOP Publishing. https://doi.org/10.1088/1742-6596/947/1/012049

Bąbel, P. (2020). Operant conditioning as a new mechanism of placebo effects. European Journal of Pain, 24(5), 902-908. https://doi.org/10.1002/ejp.1544

Bensley, D. A., \& Murtagh, M. P. (2012). Guidelines for a scientific approach to critical thinking assessment. The Teaching of Psychology,39(1), 5-16. https://doi.org/10.1177\%2F0098628311430642

Bonate, P. L. (2000). Analysis of pretest-posttest designs. Chapman and Hall/CRC. 
Cajas, F. (2001). The science/technology interaction: Implications for science literacy. Journal of Research in Science Teaching: The Official Journal of the National Association for Research in Science Teaching, 38(7), 715-729. https://doi.org/10.1002/tea.1028

Cuccio-Schirripa, S., \& Steiner, H. E. (2000). Enhancement and analysis of science question level for middle school students. Journal of Research in Science Teaching: The Official Journal of the National Association for Research in Science Teaching, 37(2), 210-224. https://onlinelibrary.wiley.com/journal/10982736

Dragoş, V., \& Mih, V. (2015). Scientific literacy in school. Procedia-Social and Behavioral Sciences, 209, 167-172. https://doi.org/10.1016/j.sbspro.2015.11.273

Drummond, C., \& Fischhoff, B. (2017). Individuals with greater science literacy and education have more polarized beliefs on controversial science topics. Proceedings of the National Academy of Sciences, 114(36), 9587-9592. https://doi.org/10.1073/pnas.1704882114

Ellis, D. (2014). Becoming a master's student. Cengage Learning.

Fakhriyah, F., Masfuah, S., Roysa, M., Rusilowati, A., \& Rahayu, E. S. (2017). Student's Science Literacy in the Aspect of Content Science?. Jurnal Pendidikan IPA Indonesia, 6(1), 81-87. https://doi.org/10.15294/jpii.v6i1.7245

Firman, F., Baedhowi, B., \& Murtini, W. (2018). The effectiveness of the scientific approach to improve student learning outcomes. International Journal of Active Learning, 3(2), 86-91.

Gordin, D. N., Polman, J. L., \& Pea, R. D. (1994). The Climate Visualizer: Sense-making through scientific visualization. Journal of Science Education and Technology, 3(4), 203-226. https://doi.org/10.1007/BF01575897

Gormally, C., Brickman, P., \& Lutz, M. (2012). Developing a test of scientific literacy skills (TOSLS): Measuring undergraduates' evaluation of scientific information and arguments. CBE-Life Sciences $\quad$ Education, 11(4), 364-377. https://doi.org/10.1187/cbe.12-03-0026

Gormally, C., Brickman, P., Hallar, B., \& Armstrong, N. (2009). Effects of inquiry-based learning on students' science literacy skills and confidence. International journal for the scholarship of teaching and learning, 3(2), 1-22. https://doi.org/10.20429/ijsotl.2009.030216

Grace, M. (2001). Gathering information 2: methods of assessment. British dental journal, 191(1), 11-18. https://doi.org/10.1038/sj.bdj.4801079a

Gunawan, I. (2017). Indonesian Curriculum 2013: Instructional management, obstacles faced by teachers in implementation, and the way forward. In 3rd International Conference on Education and Training (ICET 2017). Atlantis Press. https://doi.org/10.2991/icet17.2017.9

Gupta, S., \& Shabbir, J. (2008). On improvement in estimating the population means in simple random sampling. Journal of Applied Statistics, 35(5), 559-566. https://doi.org/10.1080/02664760701835839

Hamza, M. K., \& Griffith, K. G. (2006). Fostering problem-solving \& creative thinking in the classroom: cultivating a creative mind. In National Forum of Applied Educational Research Journal-Electronic (Vol. 9, No. 3, pp. 1-32). 
Harmsen, J. (2007). Measuring bioavailability: from a scientific approach to standard methods. Journal of Environmental Quality, 36(5), 1420-1428. https://doi.org/10.2134/jeq2006.0492

Hernawati, D., Amin, M., Al Muhdhar, M. H. I., \& Indriwati, S. E. (2019). Science literacy skills through the experience of project activities with assisted local potential-based learning materials. JPBI (Jurnal Pendidikan Biologi Indonesia), 5(1), 159-168. https://doi.org/10.22219/jpbi.v5i1.7372

Holbrook, J., \& Rannikmae, M. (2009). The meaning of scientific literacy. International Journal of Environmental and Science Education, 4(3), 275-288.

Karademir, E., \& Ulucinar, U. (2017). Examining the relationship between middle school students' critical reading skills, science literacy skills and attitudes: A structural equation modeling. Journal of Education in Science Environment and Health, 3(1), 29-39. https://doi.org/10.21891/jeseh.275669

Krahenbuhl, K. S. (2016). Student-centered education and constructivism: Challenges, concerns, and clarity for teachers. The Clearing House: A Journal of Educational Strategies, Issues, and Ideas, 89(3), 97-105. https://doi.org/10.1080/00098655.2016.1191311

Laugksch, R. C. (2000). Scientific literacy: A conceptual overview. Science education, 84(1), 71-94. $\quad$ https://doi.org/10.1002/(SICI)1098-237X(200001)84:1\%3C71::AIDSCE6\%3E3.0.CO;2-C

Lawless, K. A., Brown, S. W., Rhoads, C., Lynn, L., Newton, S. D., Brodowiksa, K., ... \& Wang, M. (2018). Promoting students' science literacy skills through a simulation of international negotiations: The GlobalEd 2 Project. Computers in Human Behavior, 78, 389-396. https://doi.org/10.1016/j.chb.2017.08.027

Miller, C. J., Smith, S. N., \& Pugatch, M. (2020). Experimental and quasi-experimental designs in implementation research. Psychiatry Research,283, 112452. https://doi.org/10.1016/j.psychres.2019.06.027

Murcia, K. (2009). Science in the news: an evaluation of students' scientific literacy. Teaching Science, 55(3), 40-45. https://doi.org/10.2307/3967356

Narut, Y. F., \& Supardi, K. (2019). Literasi sains peserta didik dalam pembelajaran ipa di Indonesia. JIPD (Jurnal Inovasi Pendidikan Dasar), 3(1), 61-69.

Putri, S. D., Ulhusna, M., Zakirman, Z., \& Gusta, W. (2020). Improvement Student Science Literacy Skills Through Edmodo-based Teaching Materials In Learning Science In Elementary School. International Journal of Scientific \& Technology Research (IJSTR), 9(3), 4649-4652.

R Surya Damayanti, R. S. D., Agus Suyatna, A. S., Warsono, W., \& Undang Rosidin, U. R. (2017). Development of Authentic Assessment instruments for Critical Thinking skills in Global Warming with a Scientific Approach. In International Journal of Science and Applied Science: Conference Series (Vol. 2, No. 1, pp. 289-299). Sebelas Maret University. https://doi.org/10.20961/ijsascs.v2i1.16730

Rahayu, S. (2017). Promoting 21st-century scientific literacy skills through innovative chemistry instruction. In AIP Conference Proceedings (Vol. 1911, No. 1, p. 020025). AIP Publishing LLC. https://doi.org/10.1063/1.5016018

Santrock, J. W. (2011). Educational psychology. McGraw-Hill. 
Sari, M. (2012). Usaha Mengatasi Problematika Pendidikan Sains di Sekolah dan Perguruan Tinggi. Al-Ta lim Journal, 19(1), 74-86. http://dx.doi.org/10.15548/jt.v19i1.9

Selasih, N. N. (2019). Implementasi Kurikulum Pendidikan Dasar Dalam Membangun Literasi Peserta Didik. Prosiding Nasional, 164-172.

Skinner, B. F. (1971). Operant conditioning. The encyclopedia of education, 7, 29-33.

Taji, A. (2005). Teaching in the sciences: Learner-centered approaches. CRC Press.

Tsevreni, I. (2011). Towards an environmental education without scientific knowledge: an attempt to create an action model based on children's experiences, emotions, and perceptions about their environment. Environmental Education Research, 17(1), 5367. https://doi.org/10.1080/13504621003637029

Vieira, R. M., \& Tenreiro-Vieira, C. (2016). Fostering scientific literacy and critical thinking in elementary science education. International Journal of science and mathematics education, 14(4), 659-680. https://doi.org/10.1007/s10763-014-9605-2

Vignoli, G. (2018). Pretest Assessment. In Urodynamics for Urogynecologists (pp. 17-30). Springer, Cham. https://doi.org/10.1007/978-3-319-74005-8_2

Waldo, J. T. (2014). Application of the test of scientific literacy skills in the assessment of a general education natural science program. The Journal of General Education, 63(1), 1-14. https://doi.org/10.1353/jge.2014.0007

Wieman, C. (2007). Why not try a scientific approach to science education?. Change: The Magazine of Higher Learning, 39(5), 9-15. https://doi.org/10.3200/chng.39.5.9-15

Wilen, W. W., \& Clegg Jr, A. A. (1986). Effective questions and questioning: A research review. Theory \& Research in Social Education, 14(2), 153-161. https://doi.org/10.1080/00933104.1986.10505518

Yusnita, A., Apriliani, S., Abbas, E. W., \& Rochgiyanti, R. (2021). The Differences of Education Unit Level Curriculum (KTSP) and The 2013 Curriculum in Social Studies Lessons. The Innovation of Social Studies Journal,3(1), 9-14. https://doi.org/10.20527/iis.v3i1.3182 